\title{
Review
}

\section{Role of genetic polymorphisms in tumour angiogenesis}

\author{
SP Balasubramanian', NJ Brown ${ }^{2}$ and MWR Reed ${ }^{* .1}$ \\ 'Academic Unit of Surgical Oncology, University of Sheffield, Sheffield SIO 2JF, UK; ${ }^{2}$ Academic Unit of Surgery, University of Sheffield, Sheffield SIO 2JF, UK
}

Angiogenesis plays a crucial role in the development, growth and spread of solid tumours. Pro- and anti-angiogenic factors are abnormally expressed in tumours, influencing tumour angiogenesis, growth and progression. Polymorphisms in genes encoding angiogenic factors or their receptors may alter protein expression and/or activity. This article reviews the literature to determine the possible role of angiogenesis-related polymorphisms in cancer. Further research studies in this potentially crucial area of tumour biology are proposed.

British Journal of Cancer (2002) 87, 1057- 1065. doi:10.1038/sj.bjc.6600625 www.bjcancer.com

(c) 2002 Cancer Research UK

Keywords: tumour angiogenesis; genetic polymorphism(s)

\section{TUMOUR ANGIOGENESIS}

Angiogenesis is a complex cascade of events involving extensive interplay between cells, soluble factors and extra-cellular matrix components. Soluble factors including cytokines have a stimulatory or inhibitory role, thereby regulating the process. The angiogenic potential of tumours was initially demonstrated in animal models and it is now recognised that angiogenesis not only precedes tumour growth, but is also necessary for metastasis. In the normal adult vasculature, a balance of the positive and negative angiogenic signals maintains quiescence. However, in the tumour microenvironment, angiogenesis occurs as there is either a preponderance of pro-angiogenic molecules or a decrease in anti-angiogenic stimuli.

\section{GENETIC POLYMORPHISMS IN ANGIOGENIC GENES AND RELEVANCE TO CANCER CARE}

Polymorphisms are naturally occurring DNA sequence variations, which differ from gene mutations in that they occur in the 'normal' healthy population and have a frequency of at least $1 \%$. Approximately $90 \%$ of DNA polymorphisms are single nucleotide polymorphisms (SNPs) due to single base substitutions. Others include insertion/deletion polymorphisms, minisatellite and microsatellite polymorphisms. Although most polymorphisms are functionally neutral, some have effects on regulation of gene expression or on the function of the coded protein. These functional polymorphisms, despite being of low penetrance, could contribute to the differences between individuals in susceptibility to and severity of disease. Certain polymorphisms alone, in combination or by interaction with environmental factors may affect the angiogenic pathway and thereby susceptibility and/or severity of cancers. Detection of the role of angiogenic gene polymorphisms that influence cancer susceptibility and/or severity may improve our understanding of tumour angiogenesis and may influence risk stratification and detection, use of new treatment strategies and prognostication of disease. The efficacy of anti-angiogenic treatment in solid cancer (Jain, 2001) could be further enhanced, if

*Correspondence: MWR Reed; E-mail: m.w.reed@sheffield.ac.uk Received 22 April 2002; revised 15 August 2002; accepted 4 September 2002 the individual angiogenic potential could be predicted on the basis of genotype.

The article reviews the role of polymorphisms in genes encoding factors and receptors that influence tumour angiogenesis. Whilst numerous polymorphisms have been identified, we have confined this review to those that are thought to be functionally important and may influence angiogenesis. Table 1 summarises the population studies that have evaluated a number of the genetic polymorphisms that will be discussed. Some 'mutations' with potential functional significance have been discussed briefly, as their prevalence in the normal population is as yet unknown. Factors/genes, which demonstrate minimal or indirect effects on angiogenesis such as tumour suppressor genes, oncogenes, hormones and hematopoietic factors, are not discussed in this review.

\section{VASCULAR ENDOTHELIAL GROWTH FACTOR}

Vascular endothelial growth factor (VEGF or VEGF-A) is one of a family of six protein isoforms expressed in different tissues including brain, kidney, liver and spleen. VEGF stimulates proliferation, migration and tube formation of endothelial cells in vitro and regulates vascular permeability in vivo (Veikkola and Alitalo, 1999). VEGF expression correlates with angiogenesis and prognosis in several tumours including breast, lung and malignant mesothelioma (Toi et al, 2001; Strizzi et al, 2001).

Several polymorphisms have been described within the promoter and $5^{\prime} \mathrm{UTR}$ of the VEGF gene, some of which $(+405 \mathrm{C}>\mathrm{G}$, $-1154 \mathrm{G}>\mathrm{A}$ and $-2578 \mathrm{C}>\mathrm{A}$ ) correlate with VEGF production. The $+405 \mathrm{C},-1154 \mathrm{G}$ and $-2578 \mathrm{C}$ alleles are associated with low VEGF production (Watson et al, 2000; Shahbazi et al, 2002a). Recent studies have shown that in individuals with the -1154 AA genotype, there may be a decrease in prostate cancer risk (McCarron et al, 2002) and reduction in invasive potential of malignant melanomas (Howell et al, 2002). This confirms earlier studies that associate reduced VEGF production with the $-1154 \mathrm{~A}$ allele.

In another study of healthy individuals, three polymorphisms (702 $\mathrm{C}>\mathrm{T}, 936 \mathrm{C}>\mathrm{T}$ and $1612 \mathrm{G}>\mathrm{A}$ ) were identified in the $3^{\prime} \mathrm{UTR}$ region of the VEGF gene. The $936 \mathrm{~T}$ allele was associated with decreased 
Table I Summary of population studies on angiogenic gene polymorphisms in solid cancer

\begin{tabular}{|c|c|c|c|c|c|c|c|c|}
\hline \multirow[b]{3}{*}{ Gene } & \multirow[b]{3}{*}{ Polymorphism } & \multirow{3}{*}{$\begin{array}{l}\text { Rare allele } \\
\text { frequency } \\
\text { in controls }\end{array}$} & \multirow[b]{3}{*}{ Cancer } & \multicolumn{2}{|c|}{ Results } & \multirow{2}{*}{\multicolumn{2}{|c|}{ Number of }} & \multirow[b]{3}{*}{ Reference } \\
\hline & & & & \multirow{2}{*}{$\begin{array}{l}\text { Tumour } \\
\text { susceptibility }\end{array}$} & \multirow{2}{*}{$\begin{array}{l}\text { Tumour } \\
\text { severity/survival }\end{array}$} & & & \\
\hline & & & & & & Cases & Controls & \\
\hline \multirow[t]{6}{*}{ VEGF } & $\begin{array}{l}-1 \mid 54 \mathrm{G}>\mathrm{A} \text { in } \\
\text { promoter }\end{array}$ & A allele $=0.34$ & $\begin{array}{l}\text { Prostate } \\
\text { cancer }\end{array}$ & $\begin{array}{l}\text { AA genotype reduces } \\
\text { risk }(O R=0.45 ; 95 \% \\
C l=0.24-0.86)\end{array}$ & No association shown & 238 & 263 & $\begin{array}{l}\text { (McCarron et al, } \\
\text { 2002) }\end{array}$ \\
\hline & $\begin{array}{l}-1154 \mathrm{G}>\mathrm{A} \text { in } \\
\text { promoter }\end{array}$ & A allele $=0.34$ & $\begin{array}{l}\text { Malignant } \\
\text { melanoma }\end{array}$ & No association shown & $\begin{array}{l}\text { VEGF }- \text { I I 54AA genotype } \\
\text { associated with thinner } \\
\text { tumours }(P=0.002)\end{array}$ & 152 & 266 & $\begin{array}{l}\text { (Howell et al, } \\
\text { 2002) }\end{array}$ \\
\hline & $\begin{array}{l}-2578 \mathrm{C}>\mathrm{A} \text { in } \\
\text { promoter }\end{array}$ & A allele $=0.48$ & $\begin{array}{l}\text { Malignant } \\
\text { melanoma }\end{array}$ & No association shown & No association shown & 134 & 266 & $\begin{array}{l}\text { (Howell et al, } \\
\text { 2002) }\end{array}$ \\
\hline & $+405 \mathrm{G}>\mathrm{C}$ in $5^{\prime} \mathrm{UTR}$ & C allele- 0.31 & $\begin{array}{l}\text { Malignant } \\
\text { melanoma }\end{array}$ & No association shown & No association shown & 137 & 241 & $\begin{array}{l}\text { (Howell et al, } \\
\text { 2002) }\end{array}$ \\
\hline & $936 \mathrm{C}>\mathrm{T}$ in $3^{\prime} \cup T R$ & $\mathrm{~T}$ allele $=0.12$ & $\begin{array}{l}\text { Malignant } \\
\text { melanoma }\end{array}$ & No association shown & No association shown & 144 & 238 & $\begin{array}{l}\text { (Howell et al, } \\
\text { 2002) }\end{array}$ \\
\hline & $936 \mathrm{C}>\mathrm{T}$ in $3^{\prime} \cup \mathrm{TR}$ & $\top$ allele $=0.13$ & Breast cancer & No association shown & No association shown & 862 & 713 & $\begin{array}{l}\text { (Balasubramanian } \\
\text { 2002) }\end{array}$ \\
\hline \multirow[t]{2}{*}{ FGFR4 } & $\begin{array}{l}\text { Glycine to Arginine } \\
\text { change at position } 388\end{array}$ & $\mathrm{Arg}^{388}$ allele $=0.31$ & Breast cancer & No association shown & $\begin{array}{l}\text { Reduced disease free survival for } \\
\mathrm{Arg}^{388} \text { carriers in patients with } \\
\text { lymph node metastases }(P=0.0 \mathrm{I})\end{array}$ & 84 & 123 & $\begin{array}{l}\text { (Bange et al, } \\
\text { 2002) }\end{array}$ \\
\hline & & & $\begin{array}{l}\text { Colonic } \\
\text { cancer }\end{array}$ & No association shown & $\begin{array}{l}\text { Rare allele associated with node } \\
\text { positivity }(P=0.00 \mid 6) \text { and } \\
\text { advanced stage }(P=0.03)\end{array}$ & 82 & 123 & $\begin{array}{l}\text { (Bange et al, } \\
\text { 2002) }\end{array}$ \\
\hline EGF & $61 \mathrm{G}>\mathrm{A}$ in $5^{\prime} \cup T R$ & G allele $=0.44$ & $\begin{array}{l}\text { Malignant } \\
\text { melanoma }\end{array}$ & $\begin{array}{l}\text { G/G genotype associated } \\
\text { with increased risk } \\
(\mathrm{OR}=4.9 \\
95 \% \mathrm{Cl}=2.3-10.2)\end{array}$ & $\begin{array}{l}\text { G/G genotype associated with } \\
\text { increased thickness }(P=0.045)\end{array}$ & 135 & 99 & $\begin{array}{l}\text { (Shahbazi et al, } \\
\text { 2002b) }\end{array}$ \\
\hline \multirow[t]{2}{*}{ Endostatin } & $\begin{array}{l}\text { G>A in exon } 42 \\
\text { (Aspartic acid to } \\
\text { Asparagine }\end{array}$ & A allele $=0.06$ & $\begin{array}{l}\text { Prostate } \\
\text { cancer }\end{array}$ & $\begin{array}{l}\text { Rare allele increases risk } \\
(\mathrm{OR}=2.4 \\
95 \% \mathrm{Cl}=1.4-4.2)\end{array}$ & No association shown & $|8|$ & 198 & $\begin{array}{l}\text { (lughetti et al, } \\
2001 \text { ) }\end{array}$ \\
\hline & & A allele $=0.08$ & Breast cancer & No association shown & $\begin{array}{l}\text { A allele associated with } \\
\text { invasiveness }(P-0.046)\end{array}$ & 861 & 697 & Unpublished data \\
\hline \multirow[t]{5}{*}{ MMP-I } & -1607 IG/2G & I G allele $=0.39$ & $\begin{array}{l}\text { Ovarian } \\
\text { cancer }\end{array}$ & $\begin{array}{l}\text { Common allele increases } \\
\text { risk }(\mathrm{OR}=2 ; 95 \% \mathrm{Cl}=\mathrm{I}-4)\end{array}$ & Not studied & 163 & 150 & $\begin{array}{l}\text { (Kanamori et al, } \\
\text { 1999) }\end{array}$ \\
\hline & & IG allele $=0.39$ & $\begin{array}{l}\text { Endometrial } \\
\text { cancer }\end{array}$ & $\begin{array}{l}\text { Common allele increases } \\
\text { risk }(P=0.019)\end{array}$ & No association shown & 100 & 150 & $\begin{array}{l}\text { (Nishioka et al, } \\
\text { 2000) }\end{array}$ \\
\hline & & IG allele $=0.25$ & Lung cancer & $\begin{array}{l}2 \mathrm{G} / 2 \mathrm{G} \text { genotype } \\
\text { increases risk }(\mathrm{OR}=1.76 \% \text {; } \\
95 \% \mathrm{Cl}=1.3-2.4)\end{array}$ & Not studied & 456 & 451 & (Zhu et al, 200I) \\
\hline & & - & $\begin{array}{l}\text { Colorectal } \\
\text { cancer }\end{array}$ & $\begin{array}{l}\text { 2G/2G genotype } \\
\text { increases risk }(\mathrm{OR}=2.2 \text {; } \\
95 \% \mathrm{Cl}=1.2-4.2)\end{array}$ & $\begin{array}{l}2 \mathrm{G} / 2 \mathrm{G} \text { genotype increases } \\
\text { risk of metastases } \\
(P=0.008)\end{array}$ & 60 & 164 & $\begin{array}{l}\text { (Ghilardi et al, } \\
200 I \text { ) }\end{array}$ \\
\hline & & - & $\begin{array}{l}\text { Malignant } \\
\text { melanoma }\end{array}$ & Not studied & $\begin{array}{l}\text { 2G allele associated with } \\
\text { deeper tumours }\end{array}$ & 139 & $\begin{array}{l}\text { No } \\
\text { controls }\end{array}$ & $\begin{array}{l}\text { (Ye et al, } \\
200 \mathrm{I})\end{array}$ \\
\hline \multirow[t]{2}{*}{ MMP-3 } & $-16125 \mathrm{~A} / 6 \mathrm{~A}$ & $5 \mathrm{~A}$ allele $=0.48$ & Breast cancer & $\begin{array}{l}\text { 5A carriers increase risk } \\
(P<0.05)\end{array}$ & Not studied & 43 & 164 & $\begin{array}{l}\text { (Biondi et al, } \\
\text { 2000) }\end{array}$ \\
\hline & & & $\begin{array}{l}\text { Colorectal } \\
\text { cancer }\end{array}$ & No association shown & Not studied & 63 & 164 & $\begin{array}{l}\text { (Biondi et al, } \\
\text { 2000) }\end{array}$ \\
\hline \multirow[t]{2}{*}{ PAI-I } & $-6754 \mathrm{G} / 5 \mathrm{G}$ & 4G allele $=0.42$ & Breast cancer & No association shown & No association shown & 100 & 106 & $\begin{array}{l}\text { (Blasiak \& } \\
\text { Smolarz, 2000) }\end{array}$ \\
\hline & & - & $\begin{array}{l}\text { Colorectal } \\
\text { cancer }\end{array}$ & Not studied & No association shown & 40 & $\begin{array}{c}\text { No } \\
\text { controls }\end{array}$ & $\begin{array}{l}\text { (Smolarz et al, } \\
200 I)\end{array}$ \\
\hline \multirow[t]{6}{*}{ TNF- $\alpha$} & $-308 \mathrm{G}>\mathrm{A}$ & A allele $=0.18$ & Breast cancer & $\begin{array}{l}\text { Homozygous rare allele } \\
\text { genotype increases risk } \\
(\mathrm{RR}=4.44 ; P=0.006)\end{array}$ & $\begin{array}{l}\text { Homozygous rare allele } \\
\text { genotype decreases disease-free } \\
\text { and overall survival }(P<0.0 \text { I) }\end{array}$ & 243 & 174 & $\begin{array}{l}\text { (Mestiri et al, } \\
200 I \text { ) }\end{array}$ \\
\hline & & A allele $=0.21$ & Breast cancer & No association shown & No association shown & 711 & 502 & Unpublished data \\
\hline & & A allele $=0.04$ & $\begin{array}{l}\text { Several (gastric } \\
\text { endometrial, } \\
\text { colorectal and } \\
\text { renal) cancers }\end{array}$ & No association shown & Not studied & 169 & 92 & $\begin{array}{l}\text { (Jang et al, } \\
200 \mathrm{Ib})\end{array}$ \\
\hline & & A allele $=0.12$ & $\begin{array}{l}\text { Colorectal } \\
\text { cancer }\end{array}$ & No association shown & No association shown & 140 & 328 & $\begin{array}{l}\text { (Park et al, } \\
\text { 1998) }\end{array}$ \\
\hline & $-238 \mathrm{G}>\mathrm{A}$ & A allele $=0.07$ & $\begin{array}{l}\text { Several (gastric } \\
\text { endometrial, } \\
\text { colorectal and } \\
\text { renal) cancers }\end{array}$ & $\begin{array}{l}\text { A allele decreases risk } \\
\text { to all these cancers } \\
(\mathrm{OR}=0.25 ; 95 \% \\
\mathrm{Cl}=0.1-0.6)\end{array}$ & Not studied & 169 & 92 & $\begin{array}{l}\text { (Jang et al, } \\
200 \mathrm{lb})\end{array}$ \\
\hline & & A allele $=0.06$ & Breast cancer & No association shown & No association shown & $7 \mid 4$ & 499 & Unpublished data \\
\hline
\end{tabular}


Table I (Continued)

\begin{tabular}{|c|c|c|c|c|c|c|c|c|}
\hline \multirow[b]{3}{*}{ Gene } & \multirow[b]{3}{*}{ Polymorphism } & \multirow{3}{*}{$\begin{array}{l}\text { Rare allele } \\
\text { frequency } \\
\text { in controls }\end{array}$} & \multirow[b]{3}{*}{ Cancer } & \multicolumn{2}{|c|}{ Results } & \multirow{2}{*}{\multicolumn{2}{|c|}{ Number of }} & \multirow[b]{3}{*}{ Reference } \\
\hline & & & & \multirow{2}{*}{$\begin{array}{l}\text { Tumour } \\
\text { susceptibility }\end{array}$} & \multirow{2}{*}{$\begin{array}{l}\text { Tumour } \\
\text { severity/survival }\end{array}$} & & & \\
\hline & & & & & & Cases & Controls & \\
\hline \multirow[t]{5}{*}{ TNF- $\beta$} & Ncol RFLP in intron I & Rare allele $=0.39$ & $\begin{array}{l}\text { Pancreatic } \\
\text { cancer }\end{array}$ & No association shown & No association with survival & 64 & 101 & $\begin{array}{l}\text { (Barber et al, } \\
\text { 1999) }\end{array}$ \\
\hline & & Rare allele $=0.30$ & Lung cancer & $\begin{array}{l}\text { TNFBI/TNFBI protects } \\
\text { against lung cancer } \\
(\mathrm{RR}=0.77 ; P=0.0 \mathrm{I})\end{array}$ & No clear significant differences & 102 & 159 & $\begin{array}{l}\text { (Shimura et al, } \\
\text { 1994) }\end{array}$ \\
\hline & & Rare allele $=0.30$ & Gastric cancer & No association shown & $\begin{array}{l}\text { Homozygous rare allele genotype } \\
\text { is associated with poor survival } \\
(P<0.05)\end{array}$ & 152 & $|4|$ & $\begin{array}{l}\text { (Shimura et al, } \\
\text { 1995) }\end{array}$ \\
\hline & & Rare allele $=0.30$ & Breast cancer & $\begin{array}{l}\text { Homozygous rare allele } \\
\text { genotype increases risk } \\
(\mathrm{OR}=5.3 ; 95 \% \\
\mathrm{Cl}=2.3-12.2)\end{array}$ & No association shown & 95 & 190 & $\begin{array}{l}\text { (Park et al, } \\
\text { 2002) }\end{array}$ \\
\hline & & Rare allele $=0.32$ & $\begin{array}{l}\text { Colorectal } \\
\text { cancer }\end{array}$ & $\begin{array}{l}\text { Homozygous rare allele } \\
\text { genotype increases risk } \\
(P<0.0 \text { I })\end{array}$ & No association shown & 136 & 331 & $\begin{array}{l}\text { (Park et al, } \\
\text { 1998) }\end{array}$ \\
\hline \multirow[t]{2}{*}{ IL-10 } & $-1082 \mathrm{G}>\mathrm{A}$ & G allele $=0.08$ & $\begin{array}{l}\text { Cervical } \\
\text { cancer }\end{array}$ & $\begin{array}{l}\text { A allele decreases risk } \\
(\mathrm{OR}=0.28 ; 95 \% \mathrm{Cl}= \\
0.1-0.6)\end{array}$ & No association shown & 77 & 69 & $\begin{array}{l}\text { (Stanczuk et al, } \\
2001 \text { ) }\end{array}$ \\
\hline & & A allele $=0.46$ & $\begin{array}{l}\text { Malignant } \\
\text { melanoma }\end{array}$ & $\begin{array}{l}\text { AA genotype increases } \\
\text { risk }(P=0.04)\end{array}$ & $\begin{array}{l}\text { AA genotype is associated with } \\
\text { advanced disease }(P=0.04)\end{array}$ & 153 & 158 & $\begin{array}{l}\text { (Howell et al, } \\
200 \mathrm{I})\end{array}$ \\
\hline
\end{tabular}

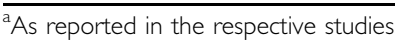

VEGF plasma levels (Renner et al, 2000). We have studied this polymorphism in breast cancer, but were unable to demonstrate any significant association (Balasubramanian et al, 2002).

\section{FIBROBLAST GROWTH FACTOR}

The fibroblast growth factor (FGF) family includes 20 polypeptide growth factors sharing a central core of 140 amino acids (Powers et al, 2000). Four receptors (FGFR 1 to 4) belonging to the immunoglobulin super family have been identified. In addition to effects on inflammation, repair and tissue regeneration, FGFs also stimulate the proliferation and migration of endothelial cells, important in the process of angiogenesis. FGFs promote tumour cell mitosis and angiogenesis and inhibit apoptosis (Powers et $a l, 2000)$. FGFs, along with VEGF, play a major role in tumour angiogenesis and their inhibition represses tumour growth (Compagni et al, 2000). To date, no activating mutations have been documented in FGFs. However, disturbances in the regulation of FGF signalling can also occur at the receptor level. FGFRs are over expressed in many human tumours (Shingu et al, 1998; Yoshimura et al, 1998; Giri et al, 1999). Many point mutations of FGFRs, found in developmental defects such as dwarfisms and craniosynostotic syndromes, result in ligand-independent activation of the FGFRs (Neilson and Friesel, 1996). A description of all these mutations is beyond the scope of this review. However, similar mutations have also been identified in human gastric cancer (FGFR2 gene) and colorectal cancer (FGFR3 gene) (Jang et al, 2001a). A mutation in the activation loop of the FGFR3 kinase domain (Lysine to Glutamic acid change), leading to constitutive activation of FGFR3, has been identified in patients with multiple myeloma, bladder and cervical carcinomas (Hart et al, 2000). In the FGFR4 gene, a common polymorphism (G>A) exists in the coding region and results in an amino acid change (glycine to arginine change) in the transmembrane domain of the receptor. Recently, it has been shown that the FGFR4 Arg 388 allele may predispose breast and colonic cancer patients to rapid disease progression (Bange et al, 2002). Such genetic changes might therefore influence the process of carcinogenesis by affecting the intracellular signal transduction cascades following FGF stimulation.
Table 2 Summary of the review

- Angiogenic factors play an important role in tumour development and progression

- Potentially functional gene polymorphisms have been described in many angiogenic genes

- Functional polymorphisms may influence tumour susceptibility and/or severity and may help in assessing risk of disease, determining prognosis and deciding the use of specific treatment regimens

- Both large-scale population studies and functional studies of these polymorphisms are urgently required.

\section{EPIDERMAL GROWTH FACTOR}

Epidermal growth factor (EGF) exerts effects on cell proliferation and differentiation by binding to a tyrosine kinase receptor EGF receptor (EGFR). Although EGF can have direct effects on tumour cells, it also promotes angiogenesis, predominantly through a mitogenic effect on endothelial cells (Dunn et al, 2000). EGF, acting through its receptor also stimulates the production of vascular endothelial growth factor by tumour cells (Goldman et al, 1993), contributing further to the angiogenic response.

A polymorphism in the $5^{\prime}$ UTR of the EGF gene (61 G>A) appears to predispose to the development of malignant melanoma. The $G$ allele is associated with higher in vitro EGF production (Shahbazi et al, 2002b).

\section{HEPATOCYTE GROWTH FACTOR/SCATTER FACTOR}

Hepatocyte growth factor (scatter factor; HGF/SF), a heparinbinding glycoprotein binds to a tyrosine kinase receptor, which is the protein product of the c-met proto-oncogene. HGF-Met signalling is involved in developmental and homeostatic processes and also regulates neoplastic growth and progression (To and Tsao, 1998). It stimulates endothelial cell proliferation and migration and regulates vascular endothelial cell growth factor expression in vascular smooth muscle cells (Van Belle et al, 1998). Increased Met and HGF/SF expression occurs in many tumours (To and Tsao, 1998) and the HGF/Met autocrine signal- 
ling pathway possibly has an oncogenic role (Takayama et al, 1997).

Somatic mutations of the c-met gene in patients with renal cell carcinoma have been shown to be oncogenic (Jeffers et al, 1997). Met is highly expressed in human gastric carcinoma cell lines, and a mutation (germ line missense Met mutation, P1009S) recently identified in gastric cancer displays increased and persistent tyrosine phosphorylation, when treated with HGF. Activating missense Met mutations could therefore contribute to gastric cancer tumorigenesis (Lee et al, 2000). Further investigations are required to determine the role of polymorphisms in the Met gene in angiogenesis and tumorigenesis.

\section{TRANSFORMING GROWTH FACTOR-BETA}

Transforming growth factor-beta (TGF- $\beta$ ) is a $25-\mathrm{kDa}$ protein which binds to three membrane molecules, TGF- $\beta$ receptors type I, II and III (Koli and Keski-Oja, 1996). TGF- $\beta$ s are potent regulators of cellular proliferation, differentiation and morphogenesis, as well as extra-cellular matrix formation, extra-cellular proteolysis, and inflammation. Although TGF- $\beta$ inhibits cell proliferation, neoplastic cells acquire resistance to this inhibitory activity. TGF$\beta$ induces angiogenesis (Pertovaara et al, 1994) and this, together with effects on stromal formation and immune function, suggests involvement in tumour progression (Gregoire and Lieubeau, 1995). In non-small cell lung cancer, TGF- $\beta 1$ protein level correlates with microvessel density and prognosis (Hasegawa et al, 2001).

Several polymorphisms have been identified in the TGF- $\beta 1$ gene and have been studied in ischaemic heart disease (Andreotti et al, 2002). One coding polymorphism, ( $\mathrm{T}>\mathrm{C}$ resulting in Leucine to Proline change) has been associated with serum TGF- $\beta 1$ levels; individuals with CC genotype having higher levels than TT or TC genotype (Yokota et al, 2000). Mutations have also been identified in the exons of TGF- $\beta 1$ gene in breast tumour samples (Cardillo et al, 1997a), ovarian tumours (Cardillo et al, 1997b) and colorectal carcinomas (Cardillo and Yap, 1997). However, as yet no correlation has been identified between these mutations and mRNA and/or protein expression in tumours.

TGFBR2, a receptor for TGF- $\beta$ lies close to or within one of the interstitial deletions that occur in $30-50 \%$ of head and neck, breast, and small cell lung cancers (Lucke et al, 2001). TGFBR2 gene mutations occur in colorectal and breast cancers and can result in absent receptor expression at the cell surface and defective TGF- $\beta$ signalling pathways (Lucke et al, 2001). Potentially, these mutations may have a significant influence on tumour progression.

\section{ENDOSTATIN}

Endostatin is a cleavage product of the $\mathrm{COOH}$-terminal domain of collagen XVIII, which inhibits endothelial cell proliferation in vitro and tumour angiogenesis and growth in vivo (O'Reilly et al, 1997). Endostatin inhibits the growth of melanoma, fibrosarcoma, renal cell, mammary and ovarian cancer (Sim et al, 2000), and is currently being assessed in clinical trials.

Several polymorphisms have been described in the Endostatin gene (chromosome 21) (Iughetti et al, 2001). One polymorphism, ( $\mathrm{G}>\mathrm{A}$ in exon 42 ), which results in the change of aspartic acid to asparagine, is associated with prostate cancer susceptibility (Iughetti et al, 2001). In our study of breast cancer patients, the rare allele of this polymorphism appears to predispose to tumour invasion (unpublished data).

\section{MATRIX METALLOPROTEINASES}

The matrix metalloproteinases (MMPs) are a family of highly conserved zinc-dependent endopeptidases with 20 members identi- fied to date. Several MMPs have been localised to a chromosomal region (in 11q23), which is amplified in many solid tumours (Curran and Murray, 1999). In addition to regulating the growth of primary and secondary tumours, MMPs promote tumour angiogenesis and metastasis by extracellular matrix remodelling. Altered MMP expression occurs in tumours of the oesophagus, stomach, colorectal, pancreatic, breast, prostate, lung and ovary with levels correlating with disease stage and possibly prognosis (Curran and Murray, 1999). MMP activity is influenced by transcription regulation, latent MMP activation, and inhibition by endogenous tissue inhibitors of metalloproteinases (TIMPs) (Ye, 2000).

Polymorphisms in human MMP genes are associated with susceptibility and/or progression of various benign and malignant conditions. MMP-1, the most widely expressed metalloproteinase degrades interstitial collagens (types I, II and III), and over expression is implicated in tumour invasion and metastasis (Ye, 2000). An insertion/deletion polymorphism at position - 1607 (1G/2G) results in increased binding (of the $2 \mathrm{G}$ allele) to recombinant Ets-1 transcription factor and increased transcriptional activity (Rutter et al, 1998). This allele is associated with increased MMP-1 expression in ovarian (Kanamori et al, 1999) and endometrial tumour samples (Nishioka et al, 2000) and found more frequently in ovarian cancer patients than in controls (Kanamori et al, 1999). Recent studies have shown that the $2 \mathrm{G}$ allele confers an increased susceptibility to lung cancer (Zhu et al, 2001) and predisposition to severe disease in colorectal tumours (Ghilardi et al, 2001) and malignant melanoma (Ye et al, 2001).

MMP-3 is also over-expressed in tumour tissues. In addition to extracellular matrix degradation, MMP3 activates gelatinase B and collagenases and releases cell surface molecules including E-cadherin, which in turn promote tumour growth (Biondi et al, 2000). A polymorphism in MMP-3 (5A/6A at position -1612 relative to the transcription track site) has been studied extensively in vascular disease. The $5 \mathrm{~A}$ allele has increased promoter activity and decreased binding to an inhibitory transcription factor (Borghaei et al, 1999). This allele has been associated with breast cancer, but not with colorectal cancer (Biondi et al, 2000). Further studies are indicated due to the small size of the study.

MMP-9 (gelatinase B) is over-expressed in both breast and colorectal cancer (Garbett et al, 1999). Of the many identified polymorphisms in the MMP-9 gene, two (a (CA)n microsatellite polymorphism at position -90 and a single nucleotide polymorphism at position -1562) are functionally significant (Shimajiri et al, 1999; Zhang et al, 1999a). Studies have shown differences in the promoter activity between different (CA)n alleles (Shimajiri et al, 1999). The $\mathrm{T}$ allele of the $\mathrm{C}-1562 \mathrm{~T}$ polymorphism demonstrates increased transcriptional activity (Ye, 2000) and is associated with severity of coronary atherosclerosis (Zhang et al, 1999b). Another polymorphism detected in MMP-12 (-82 A>G), also overexpressed in tumours, regulates MMP-12 expression (Jormsjo et al, 2000).

Tissue inhibitors of matrix metalloproteinases (TIMPs) specifically inhibit the active forms of the MMPs. There are four TIMPs (TIMP1-4) encoded by genes on different chromosomes (Apte et al, 1994). Recent research paradoxically suggests a positive correlation between TIMP levels and poor outcome (Curran and Murray, 1999). Three polymorphisms $(-899 \mathrm{~T}>\mathrm{A},-915 \mathrm{~A}>\mathrm{G}$ and $-1296 \mathrm{~T}>\mathrm{C}$ ) have been identified in the promoter region of the TIMP-3 (Beranek et al, 2000), although the functional significance is as yet unknown.

\section{PLASMINOGEN ACTIVATOR SYSTEM}

Urokinase plasminogen activator (uPA) and tissue type plasminogen activator (tPA)), activators of the plasminogen system are countered by naturally occurring plasminogen activator inhibitors (PAI). uPA belongs to a family of serine proteases and is produced 
by both normal and tumour cells. It plays a major role in embryogenesis, ovulation, wound healing, inflammation, rheumatoid arthritis and in cancer growth, angiogenesis and metastasis (Hildenbrand et al, 1995; Rabbani, 1998). High levels of uPA, $\mathrm{UPA}$ receptor (UPAR) and paradoxically PAI-1 are associated with a poor prognosis in many human cancers (Nekarda et al, 1994; Pedersen et al, 1994; Foekens et al, 2000). This may be due to excess PAI-1 release facilitating re-implantation of circulating tumour cells, as stroma formation at the metastatic site requires the blockade of uPA-mediated degradation of the extracellular matrix (Janicke et al, 1991).

Two polymorphisms have been identified in the uPA gene (Conne et al, 1997). A polymorphic microsatellite marker exists in the UPAR gene, certain alleles of which have been found in colorectal cancer cell lines but not in healthy individuals (Kohonen-Corish et al, 1996). The PAI-1 gene has several polymorphic loci including a $3^{\prime}$ HindIII restriction fragment length polymorphism, a $\mathrm{CA}(\mathrm{n})$ dinucleotide repeat in intron 3 and a $4 \mathrm{G} / 5 \mathrm{G}$ insertion/deletion at position -675 in the promoter. The smaller dinucleotide repeats are associated with higher plasma PAI-1 levels (Dawson et al, 1991) and the $-6754 \mathrm{G}$ allele demonstrates increased PAI-1 activity when compared to the $5 \mathrm{G}$ allele (Panahloo et al, 1995). Studies of the $4 \mathrm{G} / 5 \mathrm{G}$ polymorphism in small numbers of breast (Blasiak and Smolarz, 2000) and colorectal cancer patients (Smolarz et al, 2001) have not revealed any association with cancer. Larger studies are required to establish a role for polymorphisms in the PAI-1 gene.

\section{CYTOKINES}

In addition to specific angiogenic factors, certain cytokines are also involved in regulation of angiogenesis. Cytokine gene polymorphisms with a specific role in angiogenesis are therefore reviewed in the following sections.

\section{Tumour necrosis factor}

TNF- $\alpha$ Tumour necrosis factor (TNF)- $\alpha$ plays a critical role in the pathogenesis of various inflammatory, autoimmune and malignant diseases (Bazzoni and Beutler, 1996). Initially thought to have anti-tumour effects, TNF- $\alpha$ was later shown to be tumorigenic in vivo, with high plasma TNF- $\alpha$ levels associated with poor disease outcome (Warzocha et al, 1997). Stimulation of angiogenesis by TNF- $\alpha$ are well recognised, with effects modulated by other angiogenic factors (Yoshida et al, 1997).

Functional polymorphisms in the promoter region of the TNF- $\alpha$ gene at position -308 and -238 are associated with increased severity of infectious diseases, autoimmune diseases, and nonHodgkin's lymphomas (Tsukasaki et al, 2001). The functional significance of several other TNF- $\alpha$ polymorphisms have recently been reviewed in detail (Hajeer and Hutchinson, 2001). The uncommon allele of the -308 polymorphism (TNF2) is associated with higher constitutive and inducible levels of TNF- $\alpha$ (Wilson et $a l$, 1997). Individuals with the TNF2 homozygous genotype demonstrate an increased predisposition to breast cancer (RR, 4.44; $P=0.006)$. In addition, the TNF2 homozygous genotype appears to be an independent prognostic indicator for both disease free survival and overall survival (Mestiri et al, 2001). However, this polymorphism does not influence colorectal cancer risk or severity (Park et al, 1998). The -238 A allele has been reported to be protective against cancers in general (Jang et al, 2001b), but this needs to be confirmed in larger studies. We have recently studied both the -308 and -238 polymorphisms in 711 breast cancer patients and 498 age and sex-matched controls, but were unable to demonstrate any association (unpublished data). Three additional polymorphisms located in the $5^{\prime}$-flanking promoter/ enhancer region of the TNF- $\alpha$ gene at positions $-1031(\mathrm{~T}>\mathrm{C})$,
$-863(\mathrm{C}>\mathrm{A})$, and $-857(\mathrm{C}>\mathrm{T})$ are associated with $\mathrm{TNF}-\alpha$ production, all rare alleles being associated with higher levels (Higuchi et al, 1998). The TNF- $\alpha-857 \mathrm{~T}$ allele is associated with adult T-cell leukaemia/lymphoma in the Japanese population (Tsukasaki et al, 2001). The effects on angiogenesis and the presence of many functional polymorphisms in the TNF- $\alpha$ gene certainly warrant further study in neoplastic diseases.

TNF- $\beta$ (Lymphotoxin- $\alpha$ ) Structurally related to TNF- $\alpha$, stimulates the production of VEGF in prostate cancer cell lines (Ferrer et $a l, 1998)$. Increased serum levels have been associated with progression in cervical cancer (Chopra et al, 1998). A NcoI RFLP exists in the first intron of TNFB (gene for TNF- $\beta$ ); the rare allele of which $\left(\mathrm{TNFB}^{\star} 2\right)$ is associated with reduced TNF- $\beta$ production (Messer et $a l, 1991)$. The homozygous common allele genotype $\left(\mathrm{TNFB}^{\star} 1 /\right.$ $\mathrm{TNFB}^{\star} 1$ ) seems to protect against lung cancer (Shimura et al, 1994), colorectal cancer (Park et al, 1998) and breast cancer (Park et al, 2002). Studies on gastric cancer have also shown a prolonged survival in patients with this genotype (Shimura et al, 1995), whereas no association with either susceptibility or survival was demonstrated in pancreatic cancer (Barber et al, 1999).

\section{Interferons}

Interferons (IFN) have a multitude of biological effects on growth and immunity, including modulation of gene expression, inhibition of viral replication, immunomodulation, decreased cell proliferation, suppression of oncogene expression and alterations in differentiation. There are three main types: Interferon- $\alpha$, Interferon- $\beta$ (or Type I Interferons) and Interferon- $\gamma$ (Type II interferon). Several mechanisms, including inhibition of tumour angiogenesis, mediate the anti-tumour effects (Lindner and Borden, 1997). Interferon- $\alpha$ inhibits angiogenesis by down-regulating the expression of FGF-2 (Dinney et al, 1998). Interferon- $\beta$ inhibit angiogenesis, possibly by enhanced IFN-induced gene expression and this effect is enhanced when combined with Tamoxifen (Lindner and Borden, 1997).

Several polymorphisms have been described in the interferon- $\alpha$ genes (Golovleva et al, 1996; Muldoon et al, 2001). However, as majority of the members of the IFN- $\alpha$ family have widely overlapping functions, mutations in any one of the several encoding genes may only result in minor functional consequences.

Interferon- $\gamma$ induces expression of IFN-inducible protein 10 (IP10 ), a potent inhibitor of angiogenesis and tumour growth in vivo (Sgadari et al, 1996).

Of the several polymorphisms described in the IFN- $\gamma$ gene, a CA repeat polymorphism in the first intron has five alleles; the common allele (allele 2, $24 \mathrm{bp}$ long) correlates significantly with high levels of in vitro IFN- $\gamma$ production (Pravica et al, 1999). Differential binding of nuclear factors has been reported at a polymorphism $(+4766 \mathrm{C}>\mathrm{T})$ in the $3^{\prime} \mathrm{UTR}$ (Bream et al, 2000). As yet, these have not been associated with pathologies such as cancer.

\section{Interleukins}

Some Interleukins such as IL-8, IL-12, IL-10 and IL-4 influence tumour growth and angiogenesis by different mechanisms. Although several polymorphisms have been described in the encoding genes, only a few have been shown to be of functional importance. One promoter IL-10 polymorphism $(-1082 \mathrm{G}>\mathrm{A})$ influences IL-10 production. The G allele $(-1082 \mathrm{G})$ is associated with higher cytokine production (Turner et al, 1997) and may increase cervical cancer risk (Stanczuk et al, 2001) and cutaneous malignant melanoma (Howell et al, 2001). At one of the IL-4 polymorphisms $(-590 \mathrm{C}>\mathrm{T})$, the $-590 \mathrm{~T}$ allele is associated with increased promoter activity (Rosenwasser et al, 1995). This and other polymorphisms if proven to be of functional significance 
could represent potentially significant candidate genes in the regulation of tumour angiogenesis.

\section{STUDY DESIGN AND STATISTICAL CONSIDERATIONS}

Genetic polymorphisms are being increasingly evaluated for their role in multifactorial conditions, including cancer, using population case-control studies. Such studies offer many advantages when compared to family studies including:

- Recruitment of large numbers of cases and controls.

- Detection of polymorphisms that confer relative risks as low as 1.5 , which is not usually possible with family studies (Risch, 2000), thus allowing identification of low penetrance susceptibility loci.

- As cancers largely affect the middle and elderly age group, family studies like the transmission disequilibrium test and the affected sib pair analysis involving parents and sibs of patients are difficult to perform, as many will be deceased.

However, choosing an ideal control set for a population study is a difficult problem, as the age, sex and ethnicity of the case and control groups should be matched to enable appropriate conclusions to be made. Studies on functional gene polymorphisms will be more likely to yield positive results than random polymorphisms simply because of the greater prior probability of being associated with disease. However, polymorphisms in coding regions resulting in a non-conservative amino-acid substitution in conserved regions of the genome, or in potential transcription factor binding sites, are also studied because of their potential functionality. Other variants, even if not functional, can be associated with phenotype because of linkage to closely situated functional polymorphisms. It is now recognized that specific combinations of polymorphisms in a gene (haplotypes) might be of greater significance than individual polymorphisms, not only for a more efficient capture and analysis of common genetic variation (Johnson et al, 2001), but also from a functional view point (Daly and Day, 2001).

The numbers of patients and appropriately matched controls, needed to demonstrate a specific relative risk with adequate power and acceptable type I error risk in a case-control study would depend on the frequency of the polymorphism in the population. For example, to study a polymorphism with a rare allele frequency of $10 \%$ (expected to be associated with cancer with an odds ratio of 1.5) with a power of $80 \%$ and type I error rate of $0.05,558$ individuals would be required in each group. Studying rare polymorphisms $(<5 \%$ rare allele frequency) requires thousands of patients to prove small associations (odds ratio of
1.5 or lower), which may be of little biological interest because of the rarity of the polymorphism in the general population. A detailed discussion of these and related issues can be found in several recent reviews (Daly and Day, 2001; Risch, 2000; Weinberg and Umbach, 2000).

\section{CONCLUSION}

Angiogenesis is a multifactorial process regulated by a plethora of factors. Alteration in protein and/or receptor expression plays an important role in tumour angiogenesis and progression. Polymorphisms in the angiogenic genes/factors may in part explain the variation in tumour angiogenesis observed between individuals. The functional significance of polymorphisms can be determined by both in vivo studies and in vitro studies. Simultaneously, welldesigned, large case - control studies are necessary to establish associations between polymorphisms and cancer, but as yet there are few such studies.

Individual polymorphisms, even if proven to be functional, may only contribute to (and not solely determine) the heritable variation in protein levels and/or function. Many protein molecules acting along different carcinogenic pathways influence the development and spread of tumours, and hence the final outcome. It is therefore possible that specific combinations of polymorphisms within one or several genes will have a greater impact on the final phenotype than the individual polymorphisms.

We have recently established a DNA repository containing samples of over 1800 breast cancer patients and controls; primarily to identify gene polymorphisms in angiogenesis-related genes that play an important role in tumour growth and progression. We have investigated SNPs in genes including TNF- $\alpha$, VEGF and Endostatin for associations with breast cancer severity and susceptibility. Functional SNPs in the TNF- $\alpha$ promoter $(-308 \mathrm{G}>\mathrm{A}$ and $-238 \mathrm{G}>\mathrm{A}$ ), in the $3^{\prime} \mathrm{UTR}$ of the VEGF gene $(936 \mathrm{C}>\mathrm{T}$ ) (Balasubramanian et al, 2002) and in exon 42 of the Endostatin gene ( $\mathrm{G}>\mathrm{A}$ change) are not associated with breast cancer. However, the Endostatin polymorphism appears to predispose to breast tumour invasion (unpublished data).

Identification of the role of angiogenesis related gene polymorphisms in the pathogenesis of specific tumours would lead to an increased understanding of the disease process and potentially to risk stratification and prognostication. At the present time, polymorphisms in the VEGF, MMP and PA system and TNF genes seem to be promising in the quest for markers influencing the severity and extent of tumour angiogenesis. In parallel with the search for functional polymorphisms in angiogenesis related genes, epidemiological studies to detect associations of gene polymorphisms with disease phenotypes are desired.

\section{REFERENCES}

Andreotti F, Porto I, Crea F, Maseri A (2002) Inflammatory gene polymorphisms and ischaemic heart disease: review of population association studies. Heart 87: 107-112

Apte SS, Mattei MG, Olsen BR (1994) Cloning of the cDNA encoding human tissue inhibitor of metalloproteinases-3 (TIMP-3) and mapping of the TIMP3 gene to chromosome 22. Genomics 19: $86-90$

Balasubramanian SP, Brown NJ, Reed MW (2002) Role of a polymorphism in 3 '-untranslated region of vascular endothelial growth factor gene in breast cancer. Br J Surg 89: 1

Bange J, Prechtl D, Cheburkin Y, Specht K, Harbeck N, Schmitt M, Knyazeva T, Muller S, Gartner S, Sures I, Wang H, Imyanitov E, Haring HU, Knayzev P, Iacobelli S, Hofler H, Ullrich A (2002) Cancer progression and tumor cell motility are associated with the FGFR4 Arg(388) allele. Cancer Res 62: $840-847$
Barber MD, Powell JJ, Lynch SF, Gough NJ, Fearon KC, Ross JA (1999) Two polymorphisms of the tumour necrosis factor gene do not influence survival in pancreatic cancer. Clin Exp Immunol 117: 425-429

Bazzoni F, Beutler B (1996) The tumor necrosis factor ligand and receptor families. N Engl J Med 334: 1717-1725

Beranek M, Kankova K, Muzik J (2000) Identification of novel common polymorphisms in the promoter region of the TIMP-3 gene in Czech population. Mol Cell Probes 14: $265-268$

Biondi ML, Turri O, Leviti S, Seminati R, Cecchini F, Bernini M, Ghilardi G, Guagnellini E (2000) MMP1 and MMP3 polymorphisms in promoter regions and cancer. Clin Chem 46: 2023-2024

Blasiak J, Smolarz B (2000) Plasminogen activator inhibitor-1 (PAI-1) gene $4 \mathrm{G} / 5 \mathrm{G}$ promoter polymorphism is not associated with breast cancer. Acta Biochim Pol 47: 191-199 
Borghaei RC, Sullivan C, Mochan E (1999) Identification of a cytokineinduced repressor of interleukin-1 stimulated expression of stromelysin 1 (MMP-3). J Biol Chem 274: 2126-2131

Bream JH, Carrington M, O'Toole S, Dean M, Gerrard B, Shin HD, Kosack D, Modi W, Young HA, Smith MW (2000) Polymorphisms of the human IFNG gene noncoding regions. Immunogenetics 51: 50-58

Cardillo MR, Yap E (1997) TGF-betal in colonic neoplasia: a genetic molecular and immunohistochemical study. J Exp Clin Cancer Res 16: 281-288

Cardillo MR, Yap E, Castagna G (1997a) Molecular genetic analysis of TGF betal in breast cancer. J Exp Clin Cancer Res 16: 57-63

Cardillo MR, Yap E, Castagna G (1997b) Molecular genetic analysis of TGFbeta1 in ovarian neoplasia. J Exp Clin Cancer Res 16: 49-56

Chopra V, Dinh TV, Hannigan EV (1998) Circulating serum levels of cytokines and angiogenic factors in patients with cervical cancer. Cancer Invest 16: $152-159$

Compagni A, Wilgenbus P, Impagnatiello MA, Cotten M, Christofori G (2000) Fibroblast growth factors are required for efficient tumor angiogenesis. Cancer Res 60: $7163-7169$

Conne B, Berczy M, Belin D (1997) Detection of polymorphisms in the human urokinase-type plasminogen activator gene. Thromb Haemost 77: $434-435$

Curran S, Murray GI (1999) Matrix metalloproteinases in tumour invasion and metastasis. J Pathol 189: 300-308

Daly AK, Day CP (2001) Candidate gene case-control association studies: advantages and potential pitfalls. Br J Clin Pharmacol 52: 489-499

Dawson S, Hamsten A, Wiman B, Henney A, Humphries S (1991) Genetic variation at the plasminogen activator inhibitor-1 locus is associated with altered levels of plasma plasminogen activator inhibitor-1 activity. Arterioscler Thromb 11: 183-190

Dinney CP, Bielenberg DR, Perrotte P, Reich R, Eve BY, Bucana CD, Fidler IJ (1998) Inhibition of basic fibroblast growth factor expression, angiogenesis, and growth of human bladder carcinoma in mice by systemic interferon- alpha administration. Cancer Res 58: 808-814

Dunn IF, Heese O, Black PM (2000) Growth factors in glioma angiogenesis: FGFs, PDGF, EGF, and TGFs. J Neurooncol 50: 121-137

Ferrer FA, Miller LJ, Andrawis RI, Kurtzman SH, Albertsen PC, Laudone VP, Kreutzer DL (1998) Angiogenesis and prostate cancer: in vivo and in vitro expression of angiogenesis factors by prostate cancer cells. Urology 51: $161-167$

Foekens JA, Peters HA, Look MP, Portengen H, Schmitt M, Kramer MD, Brunner N, Janicke F, Meijer-van Gelder ME, Henzen-Logmans SC, van Putten WL, Klijn JG (2000) The urokinase system of plasminogen activation and prognosis in 2780 breast cancer patients. Cancer Res 60: 636-643

Garbett EA, Reed MW, Brown NJ (1999) Proteolysis in human breast and colorectal cancer. Br J Cancer 81: 287-293

Ghilardi G, Biondi ML, Mangoni J, Leviti S, DeMonti M, Guagnellini E, Scorza R (2001) Matrix metalloproteinase-1 promoter polymorphism $1 \mathrm{G} / 2 \mathrm{G}$ is correlated with colorectal cancer invasiveness. Clin Cancer Res 7: $2344-$ 2346

Giri D, Ropiquet F, Ittmann M (1999) Alterations in expression of basic fibroblast growth factor (FGF) 2 and its receptor FGFR-1 in human prostate cancer. Clin Cancer Res 5: $1063-1071$

Goldman CK, Kim J, Wong WL, King V, Brock T, Gillespie GY (1993) Epidermal growth factor stimulates vascular endothelial growth factor production by human malignant glioma cells: a model of glioblastoma multiforme pathophysiology. Mol Biol Cell 4: 121-133

Golovleva I, Kandefer-Szerszen M, Beckman L, Lundgren E (1996) Polymorphism in the interferon-alpha gene family. Am J Hum Genet 59: $570-578$

Gregoire M, Lieubeau B (1995) The role of fibroblasts in tumor behavior. Cancer Metastasis Rev 14: 339-350

Hajeer AH, Hutchinson IV (2001) Influence of TNFalpha gene polymorphisms on TNFalpha production and disease. Hum Immunol 62: 1191-1199

Hart KC, Robertson SC, Kanemitsu MY, Meyer AN, Tynan JA, Donoghue DJ (2000) Transformation and Stat activation by derivatives of FGFR1, FGFR3, and FGFR4. Oncogene 19: 3309-3320

Hasegawa Y, Takanashi S, Kanehira Y, Tsushima T, Imai T, Okumura K (2001) Transforming growth factor-betal level correlates with angiogenesis, tumor progression, and prognosis in patients with nonsmall cell lung carcinoma. Cancer 91: 964-971

Higuchi T, Seki N, Kamizono S, Yamada A, Kimura A, Kato H, Itoh K (1998) Polymorphism of the $5^{\prime}$-flanking region of the human tumor necrosis factor (TNF)-alpha gene in Japanese. Tissue Antigens 51: 605-612
Hildenbrand R, Dilger I, Horlin A, Stutte HJ (1995) Urokinase and macrophages in tumour angiogenesis. Br J Cancer 72: 818-823

Howell WM, Bateman AC, Turner SJ, Collins A, Theaker JM (2002) Influence of vascular endothelial growth factor single nucleotide polymorphisms on tumour development in cutaneous malignant melanoma. Genes Immun 3: $229-232$

Howell WM, Turner SJ, Bateman AC, Theaker JM (2001) IL-10 promoter polymorphisms influence tumour development in cutaneous malignant melanoma. Genes Immun 2: 25-31

Iughetti P, Suzuki O, Godoi PH, Alves VA, Sertie AL, Zorick T, Soares F, Camargo A, Moreira ES, di Loreto C, Moreira-Filho CA, Simpson A, Oliva G, Passos-Bueno MR (2001) A polymorphism in endostatin, an angiogenesis inhibitor, predisposes for the development of prostatic adenocarcinoma. Cancer Res 61: 7375-7378

Jain RK (2001) Normalizing tumor vasculature with anti-angiogenic therapy: a new paradigm for combination therapy. Nat Med 7: 987-989

Jang JH, Shin KH, Park JG (2001a) Mutations in fibroblast growth factor receptor 2 and fibroblast growth factor receptor 3 genes associated with human gastric and colorectal cancers. Cancer Res 61: 3541-3543

Jang WH, Yang YI, Yea SS, Lee YJ, Chun JH, Kim HI, Kim MS, Paik KH (2001b) The -238 tumor necrosis factor-alpha promoter polymorphism is associated with decreased susceptibility to cancers. Cancer Lett 166: $41-46$

Janicke F, Schmitt M, Graeff H (1991) Clinical relevance of the urokinasetype and tissue-type plasminogen activators and of their type 1 inhibitor in breast cancer. Semin Thromb Hemost 17: 303-312

Jeffers M, Schmidt L, Nakaigawa N, Webb CP, Weirich G, Kishida T, Zbar B, Vande Woude GF (1997) Activating mutations for the met tyrosine kinase receptor in human cancer. Proc Natl Acad Sci USA 94: 11445-11450

Johnson GC, Esposito L, Barratt BJ, Smith AN, Heward J, Di Genova G, Ueda H, Cordell HJ, Eaves IA, Dudbridge F, Twells RC, Payne F, Hughes W, Nutland S, Stevens H, Carr P, Tuomilehto-Wolf E, Tuomilehto J, Gough SC, Clayton DG, Todd JA (2001) Haplotype tagging for the identification of common disease genes. Nat Genet 29: 233-237

Jormsjo S, Ye S, Moritz J, Walter DH, Dimmeler S, Zeiher AM, Henney A, Hamsten A, Eriksson P (2000) Allele-specific regulation of matrix metalloproteinase-12 gene activity is associated with coronary artery luminal dimensions in diabetic patients with manifest coronary artery disease. Circ Res 86: $998-1003$

Kanamori Y, Matsushima M, Minaguchi T, Kobayashi K, Sagae S, Kudo R, Terakawa N, Nakamura Y (1999) Correlation between expression of the matrix metalloproteinase- 1 gene in ovarian cancers and an insertion/deletion polymorphism in its promoter region. Cancer Res 59: 4225-4227

Kohonen-Corish MR, Wang Y, Doe WF (1996) A highly polymorphic CA/GT repeat in intron 3 of the human urokinase receptor gene (PLAUR). Hum Genet 97: $124-125$

Koli K, Keski-Oja J (1996) Transforming growth factor-beta system and its regulation by members of the steroid-thyroid hormone superfamily. $A d v$ Cancer Res 70: $63-94$

Lee JH, Han SU, Cho H, Jennings B, Gerrard B, Dean M, Schmidt L, Zbar B, Vande Woude GF (2000) A novel germ line juxtamembrane Met mutation in human gastric cancer. Oncogene 19: 4947-4953

Lindner DJ, Borden EC (1997) Effects of tamoxifen and interferon-beta or the combination on tumor-induced angiogenesis. Int J Cancer 71: 456-461

Lucke CD, Philpott A, Metcalfe JC, Thompson AM, Hughes-Davies L, Kemp PR, Hesketh R (2001) Inhibiting mutations in the transforming growth factor beta type 2 receptor in recurrent human breast cancer. Cancer Res 61: $482-485$

McCarron SL, Edwards S, Evans PR, Gibbs R, Dearnaley DP, Dowe A, Southgate C, Easton DF, Eeles RA, Howell WM (2002) Influence of cytokine gene polymorphisms on the development of prostate cancer. Cancer Res 62: $3369-3372$

Messer G, Spengler U, Jung MC, Honold G, Blomer K, Pape GR, Riethmuller G, Weiss EH (1991) Polymorphic structure of the tumor necrosis factor (TNF) locus: an NcoI polymorphism in the first intron of the human TNF-beta gene correlates with a variant amino acid in position 26 and a reduced level of TNF- beta production. J Exp Med 173: 209-219

Mestiri S, Bouaouina N, Ahmed SB, Khedhaier A, Jrad BB, Remadi S, Chouchane L (2001) Genetic variation in the tumor necrosis factor-alpha promoter region and in the stress protein hsp70-2: susceptibility and prognostic implications in breast carcinoma. Cancer 91: 672-678

Muldoon J, Uriel A, Khoo S, Ollier WE, Hajeer AH (2001) Novel IFN-alpha receptor promoter polymorphisms. Genes Immun 2: 159- 160 
Neilson KM, Friesel R (1996) Ligand-independent activation of fibroblas growth factor receptors by point mutations in the extracellular, transmembrane, and kinase domains. J Biol Chem 271: 25049-25057

Nekarda H, Schmitt M, Ulm K, Wenninger A, Vogelsang H, Becker K, Roder JD, Fink U, Siewert JR (1994) Prognostic impact of urokinase-type plasminogen activator and its inhibitor PAI-1 in completely resected gastric cancer. Cancer Res 54: 2900-2907

Nishioka Y, Kobayashi K, Sagae S, Ishioka S, Nishikawa A, Matsushima M, Kanamori Y, Minaguchi T, Nakamura Y, Tokino T, Kudo R (2000) A single nucleotide polymorphism in the matrix metalloproteinase-1 promoter in endometrial carcinomas. Jpn J Cancer Res 91: 612-615

O’Reilly MS, Boehm T, Shing Y, Fukai N, Vasios G, Lane WS, Flynn E, Birkhead JR, Olsen BR, Folkman J (1997) Endostatin: an endogenous inhibitor of angiogenesis and tumor growth. Cell 88: 277-285

Panahloo A, Mohamed-Ali V, Lane A, Green F, Humphries SE, Yudkin IS (1995) Determinants of plasminogen activator inhibitor 1 activity in treated NIDDM and its relation to a polymorphism in the plasminogen activator inhibitor 1 gene. Diabetes 44: 37-42

Park KS, Mok JW, Ko HE, Tokunaga K, Lee MH (2002) Polymorphisms of tumour necrosis factors A and B in breast cancer. Eur J Immunogenet 29: $7-10$

Park KS, Mok JW, Rho SA, Kim JC (1998) Analysis of TNFB and TNFA NcoI RFLP in colorectal cancer. Mol Cells 8: 246-249

Pedersen H, Brunner N, Francis D, Osterlind K, Ronne E, Hansen HH, Dano K, Grondahl-Hansen J (1994) Prognostic impact of urokinase, urokinase receptor, and type 1 plasminogen activator inhibitor in squamous and large cell lung cancer tissue. Cancer Res 54: 4671-4675

Pertovaara L, Kaipainen A, Mustonen T, Orpana A, Ferrara N, Saksela O, Alitalo K (1994) Vascular endothelial growth factor is induced in response to transforming growth factor-beta in fibroblastic and epithelial cells. J Biol Chem 269: 6271-6274

Powers CJ, McLeskey SW, Wellstein A (2000) Fibroblast growth factors, their receptors and signaling. Endocr Relat Cancer 7: 165-197

Pravica V, Asderakis A, Perrey C, Hajeer A, Sinnott PJ, Hutchinson IV (1999) In vitro production of IFN-gamma correlates with CA repeat polymorphism in the human IFN-gamma gene. Eur J Immunogenet 26: 1-3

Rabbani SA (1998) Metalloproteases and urokinase in angiogenesis and tumor progression. In Vivo 12: $135-142$

Renner W, Kotschan S, Hoffmann C, Obermayer-Pietsch B, Pilger E (2000) A common $936 \mathrm{C} / \mathrm{T}$ mutation in the gene for vascular endothelial growth factor is associated with vascular endothelial growth factor plasma levels. J Vasc Res 37: $443-448$

Risch NJ (2000) Searching for genetic determinants in the new millennium. Nature 405: $847-856$

Rosenwasser LJ, Klemm DJ, Dresback JK, Inamura H, Mascali JJ, Klinnert M, Borish L (1995) Promoter polymorphisms in the chromosome 5 gene cluster in asthma and atopy. Clin Exp Allergy 25(Suppl 2): 74-78 discussion $95-96$

Rutter JL, Mitchell TI, Buttice G, Meyers J, Gusella JF, Ozelius LJ, Brinckerhoff CE (1998) A single nucleotide polymorphism in the matrix metalloproteinase-1 promoter creates an Ets binding site and augments transcription. Cancer Res 58: $5321-5325$

Sgadari C, Angiolillo AL, Tosato G (1996) Inhibition of angiogenesis by interleukin-12 is mediated by the interferon-inducible protein 10. Blood 87: $3877-3882$

Shahbazi M, Fryer AA, Pravica V, Brogan IJ, Ramsay HM, Hutchinson IV, Harden PN (2002a) Vascular endothelial growth factor gene polymorphisms are associated with acute renal allograft rejection. J Am Soc Nephrol 13: $260-264$

Shahbazi M, Pravica V, Nasreen N, Fakhoury H, Fryer AA, Strange RC, Hutchinson PE, Osborne JE, Lear JT, Smith AG, Hutchinson IV (2002b) Association between functional polymorphism in EGF gene and malignant melanoma. Lancet 359: 397-401

Shimajiri S, Arima N, Tanimoto A, Murata Y, Hamada T, Wang KY, Sasaguri Y (1999) Shortened microsatellite $d(C A) 21$ sequence down-regulates promoter activity of matrix metalloproteinase 9 gene. FEBS Lett 455: $70-74$

Shimura T, Hagihara M, Takebe K, Munkhbat B, Odaka T, Kato H, Nagamachi Y, Tsuji K (1994) The study of tumor necrosis factor beta gene polymorphism in lung cancer patients. Cancer 73: 1184-1188

Shimura T, Hagihara M, Takebe K, Munkhbat B, Ogoshi K, Mitomi T, Nagamachi Y, Tsuji K (1995) 10.5-kb homozygote of tumor necrosis factor-beta gene is associated with a better prognosis in gastric cancer patients. Cancer 75: $1450-1453$
Shingu K, Fujimori M, Ito K, Hama Y, Kasuga Y, Kobayashi S, Itoh N, Amano J (1998) Expression of fibroblast growth factor-2 and fibroblast growth factor receptor-1 in thyroid diseases: difference between neoplasms and hyperplastic lesions. Endocr J 45: 35-43

Sim BK, MacDonald NJ, Gubish ER (2000) Angiostatin and endostatin: endogenous inhibitors of tumor growth. Cancer Metastasis Rev 19: 181 190

Smolarz B, Blasiak J, Kulig A, Romanowicz-Makowska H, Dziki A, Ulanska J, Pander B, Szewczyk T (2001) Plasminogen activator inhibitor 1 (PAI-1) levels and gene promoter polymorphisms in subjects with colorectal cancer. J Exp Clin Cancer Res 20: 247-252

Stanczuk GA, Sibanda EN, Perrey C, Chirara M, Pravica V, Hutchinson IV, Tswana SA (2001) Cancer of the uterine cervix may be significantly associated with a gene polymorphism coding for increased IL-10 production. Int J Cancer 94: $792-794$

Strizzi L, Catalano A, Vianale G, Orecchia S, Casalini A, Tassi G, Puntoni R, Mutti L, Procopio A (2001) Vascular endothelial growth factor is an autocrine growth factor in human malignant mesothelioma. J Pathol 193: 468 475

Takayama H, LaRochelle WJ, Sharp R, Otsuka T, Kriebel P, Anver M, Aaronson SA, Merlino G (1997) Diverse tumorigenesis associated with aberrant development in mice overexpressing hepatocyte growth factor/scatter factor. Proc Natl Acad Sci USA 94: 701-706

To CT, Tsao MS (1998) The roles of hepatocyte growth factor/scatter factor and met receptor in human cancers (Review). Oncol Rep 5: 1013-1024

Toi M, Matsumoto T, Bando H (2001) Vascular endothelial growth factor: its prognostic, predictive, and therapeutic implications. Lancet Oncol 2: $667-$ 673

Tsukasaki K, Miller CW, Kubota T, Takeuchi S, Fujimoto T, Ikeda S, Tomonaga M, Koeffler HP (2001) Tumor necrosis factor alpha polymorphism associated with increased susceptibility to development of adult T-cell leukemia/lymphoma in human T-lymphotropic virus type 1 carriers. Cancer Res 61: 3770-3774

Turner DM, Williams DM, Sankaran D, Lazarus M, Sinnott PJ, Hutchinson IV (1997) An investigation of polymorphism in the interleukin-10 gene promoter. Eur J Immunogenet 24: 1-8

Van Belle E, Witzenbichler B, Chen D, Silver M, Chang L, Schwall R, Isner JM (1998) Potentiated angiogenic effect of scatter factor/hepatocyte growth factor via induction of vascular endothelial growth factor: the case for paracrine amplification of angiogenesis. Circulation 97: 381-390

Veikkola T, Alitalo K (1999) VEGFs, receptors and angiogenesis. Semin Cancer Biol 9: 211-220

Warzocha K, Salles G, Bienvenu J, Bastion Y, Dumontet C, Renard N, Neidhardt-Berard EM, Coiffier B (1997) Tumor necrosis factor ligand-receptor system can predict treatment outcome in lymphoma patients. J Clin Oncol 15: $499-508$

Watson CJ, Webb NJ, Bottomley MJ, Brenchley PE (2000) Identification of polymorphisms within the vascular endothelial growth factor (VEGF) gene: correlation with variation in VEGF protein production. Cytokine 12: $1232-1235$

Weinberg CR, Umbach DM (2000) Choosing a retrospective design to assess joint genetic and environmental contributions to risk. Am J Epidemiol 152: $197-203$

Wilson AG, Symons JA, McDowell TL, McDevitt HO, Duff GW (1997) Effects of a polymorphism in the human tumor necrosis factor alpha promoter on transcriptional activation. Proc Natl Acad Sci USA 94: $3195-3199$

Ye S (2000) Polymorphism in matrix metalloproteinase gene promoters: implication in regulation of gene expression and susceptibility of various diseases. Matrix Biol 19: 623-629

Ye S, Dhillon S, Turner SJ, Bateman AC, Theaker JM, Pickering RM, Day I, Howell WM (2001) Invasiveness of cutaneous malignant melanoma is influenced by matrix metalloproteinase 1 gene polymorphism. Cancer Res 61: 1296-1298

Yokota M, Ichihara S, Lin TL, Nakashima N, Yamada Y (2000) Association of a T29- > C polymorphism of the transforming growth factor- betal gene with genetic susceptibility to myocardial infarction in Japanese. Circulation 101: $2783-2787$

Yoshida S, Ono M, Shono T, Izumi H, Ishibashi T, Suzuki H, Kuwano M (1997) Involvement of interleukin-8, vascular endothelial growth factor, and basic fibroblast growth factor in tumor necrosis factor alpha-dependent angiogenesis. Mol Cell Biol 17: 4015-4023 
Yoshimura N, Sano H, Hashiramoto A, Yamada R, Nakajima H, Kondo M, Oka T (1998) The expression and localization of fibroblast growth factor-1 (FGF-1) and FGF receptor-1 (FGFR-1) in human breast cancer. Clin Immunol Immunopathol 89: 28-34

Zhang B, Henney A, Eriksson P, Hamsten A, Watkins H, Ye S (1999a) Genetic variation at the matrix metalloproteinase- 9 locus on chromosome 20q12.2-13.1. Hum Genet 105: 418-423
Zhang B, Ye S, Herrmann SM, Eriksson P, de Maat M, Evans A, Arveiler D, Luc G, Cambien F, Hamsten A, Watkins H, Henney AM (1999b) Functional polymorphism in the regulatory region of gelatinase $\mathrm{B}$ gene in relation to severity of coronary atherosclerosis. Circulation 99: $1788-1794$

Zhu Y, Spitz MR, Lei L, Mills GB, Wu X (2001) A single nucleotide polymorphism in the matrix metalloproteinase-1 promoter enhances lung cancer susceptibility. Cancer Res 61: 7825-7829 